В. Ю. Підгурська,

кандидат педагогічних наук, доцент

(Житомирський державний університет імені Івана Франка)

pidgurskavalentyna@gmail.com

ORCID: 0000-0002-9882-6390

\title{
ФОРМУВАННЯ МОВНОЇ КУЛЬТУРИ МАЙБУТНІХ ФАХІВЦІВ НА ЗАНЯТТЯХ 3 УКРАЇНСЬКОЇ МОВИ (ЗА ПРОФЕСІЙНИМ СПРЯМУВАННЯМ)
}

У статті розкрито зміст понять "культура мови" $i$ "мовні норми" у площчині проблеми становлення майбутніх фахівиів. Зокрема розглянуто проблему формування мовної культури студентів-нефілологів на заняттях з украӥнської мови (за професійним спрямуванням); визначено місче навчального курсу в системі підготовки бакалаврів. 3'ясовано мету й завдання курсу в контексті формування творчої мовнокомунікативної особистості майбутнього фахівия. Наведено приклади практико орієнтованих завдань на формування вмінь і навичок правильного використання лексичних, акцентуачійних, орфографічних, стилістичних, граматичних норм сучасної украӥнської літературної мови.

Ключові слова: сучасна украӥнська літературна мова, мовна культура, мовні норми, українська мова (за професійним спрямуванням), тренувальні вправи.

Постановка проблеми. Українська літературна мова охоплює всі сфери життя сучасної людини, зокрема: державні та громадські установи, засоби масової інформації, науку, мистецтво, освіту, побут. Серед визначальних ознак літературної мови виділимо нормативність. Т. Гриценко під нормою літературної мови розуміє сукупність мовних засобів, що відповідають системі мови й сприймаються ії носіями як зразок суспільного спілкування в певний період розвитку мови та суспільства [1: 39]. Нормативність передбачає наявність загальноприйнятих для певної епохи норм: орфоепічних, акцентуаційних, правописних, лексичних, словотворчих, граматичних, стилістичних. Саме нормативність $€$ предметом дослідження культури мови.

Л. Струганець пропонує таке визначення поняття "культура мови": 1) сукупність комунікативних якостей літературної мови, що виявляються за різних умов спілкування відповідно до мети і змісту висловлювання; 2) культивування (удосконалення) літературної мови й індивідуального мовлення, виявлення тенденцій мовного розвитку, реальне втілення в мовній практиці норм літературної мови, відповідна мовна політика в державі; 3) самостійна лінгвістична дисципліна, яка вивчає стан і статус норм сучасної української літературної мови в певну епоху, а також рівень лінгвістичної компетенції мовних особистостей [2: 31].

На думку В. Русанівського, культура мови покликана оцінювати доречність, доцільність або недоречність, недоцільність використання різних засобів мовного вираження. Вона виступає тим чутливим інструментом, що першим помічає нові явища в лексиці, фразеології граматиці, підказує мовцям стилістичне забарвлення мовних форм, попереджає про втрату словом його інформативного й емоційного заряду [3: 10]. Оволодіння культурою мови є передумовою багатства внутрішнього світу людини, барометром духовної зрілості нації. Культура мови - це своєрідна візитівка, відповідно до того, як людина говорить, можна визначити іiі інтелектуальний рівень і творчий потенціал [4: 167]. Серед головних завдань культури мови виокремлюють такі: виховання навичок літературного спілкування; пропаганда й засвоєння літературних норм у слововжитку, граматичному оформленні мови; у вимові й наголошуванні; неприйнятті спотвореної мови або суржику [5: 127]. Значення культури мови підкреслюється і в чинному Законі України "Про засади державної мовної політики". Згідно із пунктом 4 статті 6, норми української мови встановлюються у словниках української мови та українському правописі; також наголошується на державній підтримці використання нормативної форми української мови в засобах масової інформації, інших публічних сферах [6]. Поза всяким сумнівом, послідовна робота $з$ опанування культури усного й писемного мовлення $є$ необхідним чинником професійного становлення майбутніх спеціалістів у будь-якій галузі народного господарства.

Аналіз актуальних досліджень. Проблему формування культури мовлення студентів-нефілологів досліджували Л. Бабай, Н. Бабич, М. Вашуленко, І. Голубовська, А. Капська, К. Климова, А. Коваль, К. Козирєва, Т. Лепеха, Л. Мацько, Г. Онуфрієнко, В. Підгурська, Г. Сагач, З. Сікорська, Л. Шевченко та ін. Тривалий час майбутні фахівці вивчали курс "Основи культури і техніки мовлення". Провідна мета вказаної дисципліни - систематизація знань студентів про комунікативні якості мовлення, розширення уявлень про роль і місце культури мовлення в житті людей та про завдання освітніх закладів у процесі гуманітаризації суспільства, а також формування творчої риторичної особистості студентів [7: 32]. 
Чинними навчальними планами для вітчизняних ВНЗ не передбачено вивчення згаданого навчального предмету; однак викладачі-словесники докладають усіх зусиль для підвищення рівня мовної культури майбутніх бакалаврів. У зв’язку з цим особливу роль відіграє курс "Українська мова (за професійним спрямуванням)" - власне, єдина лінгвістична дисципліна, яка поглиблює та систематизує знання студентів нефілологічних спеціальностей про різні рівні української мови, про іiі стилістичні розшарування, про специфіку професійної та наукової комунікації, а також розширює уявлення майбутніх професіоналів про роль і місце культури мови й мовлення. На лекційних та практичних заняттях сучасні студенти ВНЗ мають оволодіти нормами літературної мови, опанувати основні комунікативні якості мовлення, навчитися складати й редагувати тексти різних стилів, збагатити власний лексичний запас, підвищити загальний рівень орфографічної, пунктуаційної та лексико-стилістичної грамотності тощо.

Мета статті: визначити оптимальні шляхи формування мовної культури майбутніх фахівців на заняттях з української мови (за професійним спрямуванням).

\section{Завдання дослідження:}

- визначення специфіки курсу "Українська мова (за професійним спрямуванням)" у площині можливостей для підвищення рівня мовної культури студентів-нефілологів; розробка завдань для удосконалення культури мовлення майбутніх фахівців.

Виклад основного матеріалу. Відповідно до наказу № 1150 від 21.12.09 року Міністерства освіти і науки України, навчальна програма С. Шевчук та I. Клименко 3 дисципліни "Українська мова (за професійним спрямуванням)" [8] обов'язкова для вивчення у вітчизняних ВНЗ. Програмою передбачено вивчення низки питань, що висвітлюють окремі аспекти культури мови:

1. Мовні норми.

2. Комунікативні ознаки культури мови.

3. Мова й культура мовлення в житті професійного комунікатора.

4. Роль словників у підвищенні мовленнєвої культури.

5. Типові помилки під час перекладу наукових текстів українською.

6. Особливості редагування наукового тексту. Помилки у змісті й будові висловлювань.

У процесі викладання дисципліни "Українська мова (за професійним спрямуванням)" доречно використовувати такі завдання, як: підготовка повідомлень із проблем культури мовлення; тренувальні вправи для самостійного виконання; реферування запропонованих для вивчення наукових праць; укладання словника наголосів; ведення термінологічного словника 3 курсу. Пропонуємо приклади різнопланових практичних завдань, виконання яких може підвищити загальний рівень мовленнєвої культури студентів.

Завдання 1. Виправте ненормативні словосполучення, визначте причини виникнення помилок.

Відношення в класі, стане в нагоді, вірна відповідь, писати в стрічку, здати залік, толковий школяр, завдяки хворобі, урочисте міроприємство, товари в розстрочку, дошка об'яв, виписка з протоколу, об'єм твору, підняти руку, на протязі місяця, не хватає слів, приймати участь, учбове заняття, зробити підсумки, підбити висновки, віддавати собі звіт, виступити по проблемі, повістка дня, стан ефекту, підняти руку, заглиблювати знання.

Завдання 2. Підготуйте повідомлення з проблем слововживання.

Адрес - адреса; багато - чимало; відносини - взаємини - стосунки; гуманітарний - гуманний гуманістичний; приводити - призводити; зміст - значення; комфортний - комфортабельний; пам'ятний меморіальний; наголосити - підкреслити; шар - пласт - верства; уявлення - уява; водій - шофер.

Завдання 3. Перекладіть українською словосполучення офіиійно-ділового стилю.

Объяснительная записка, устав предприятия, деловое общение, приказ об отчислении, физическое лицо, деловое совещание, отчетный доклад, рассчитываться наличными, вышестоящие организации, отправить письмо до востребования, лицевой счет, командировочное удостоверение, приказ о поощрении работника, трудовое соглашение, координационный совет, потребительская карта, причиненный ущерб, осталось в наличии, оптом и в розницу, отпуск за свой счет.

Завдання 4. Користуючись словником, знайдіть українські відповідники російським фразеологізмам, а також поясніть їх значення.

В подметки не годится; гиблое дело; в противном случае; бразды правления; всяк сверчок знай свой шесток; выносить сор из избы; как с козла молока; как аукнется, так и откликнется; наш пострел везде поспел; верста коломенская; тянуть канитель; опять двадцать пять; сбоку припека; понести убыток; и всё такое; забить тревогу; ушки на макушке.

Завдання 5. Запишіть подані слова у дві колонки: у першу - слова, щзо мають подвійний наголос, у другу - слова, щчо мають омографи.

Атлас, бажаний, басма, білизна, вершковий, вигода, виходити, відомість, гладкий, господарський, договір, доповідач, жмуритися, завжди, зав'язка, заголовок, заклад, замковий, затишно, ірис, людський, мабуть, об'єднання, помилка, простий, прошу, роки, танковий, типовий, тисячі, характерний, ядерний. 
Завдання 6. Подані іменники перекладіть украӥнською мовою. Украӥнські та російські слова запишіть у дві колонки та визначте форму роду (там, де можна).

Агентство, боль, Вена, генезис, георгин, дверь, дробь, жатва, жеребенок, звукопись, корь, котенок, кофе, кризис, мебель, морковь, надпись, насыпь, похороны, путь, ребенок, ревность, рукопись, Сибирь, собака, степь, сыпь, тезис, теленок, тюль, филиал, чернила, шампунь.

Завдання 7. Поясніть значення поданих фразеологізмів.

Авгієві стайні, альфа і омега, аркадська ідилія, блудний син, восьме чудо світу, всесвітній потоп, гомеричний сміх, гордіїв вузол, дамоклів меч, езопова мова, лавровий вінок, манна небесна, між Сціллою і Харібдою, муки Тантала, нитка Аріадни, ноїв ковчег, офірний цап, прокрустове ложе, ріг достатку, свята простота, соломонове рішення, скринька Пандори, сізіфова праця, терновий вінок, троянський кінь, умивати руки, юдин поцілунок, юдині срібняки, яблуко розбрату.

Завдання 8. Використовуючи подані слова, сформуйте пари з українських слів та їхніх іншомовних відповідників.

Асиміляція, бездіяльний, переважний, прогноз, прецедент, менеджер, вертоліт, потрясіння, уподібнення, фальсифікація, симптом, одночасний, відтінок, мобільність, примара, синхронний, незвичайний, фантом, інтенсивний, ознака, напружений, екстраординарний, нюанс, обізнаність, правопис, домінантний, аргумент, пасивний, передбачення, стрес, компетентність, орфографія, випадок, гелікоптер, підроблення, доказ, управлінець, рухомість.

Завдання 9. Розкрийте значення паронімів. 3 трьома парами паронімів (за власним вибором) складіть речення.

Абонент - абонемент; адрес - адреса; анафора - анафема; афект - ефект; гарнітура - гарнітур; громадянський - громадський; дефект - дефектолог; дискримінація - дискредитація; ефектний ефективний; економний - економічний; інцидент - прецедент; кар'єр - кар'єра; комунікаційний комунікабельний; нагода - пригода; реклама - рекламація; стимуляція - симуляція; спільний суспільний; статичний - статистичний; фатальний - тотальний.

Завдання 10. Прочитайте ичитати із студентських модульних робіт та охарактеризуйте мовні помилки. Відредагуйте речення.

1) В "Абетці" Льва Толстого відбив багаторічний досвід роботи в японській школі. 2) У статті "Женщина-мати" Іван Франко показує турботливу маму, жінку, яка, вкладаючи дітей спати, читає їм казки, їі тонку душу. 3) Поступово з цього хлопчика підріс підліток, а згодом добрий молодик. 4) У кінці казки щасливий кінець. 5) У романі-епопеї описується життя людини, не відриваючи суспільного життя. 6) Тарас Шевченко $є$ цінним вкладом в українській літературній спадщині. 7) Син також пішов татовими кроками. 8) Сила казки в тому, що дуже сильно показане життя Івана. 9) Сюжет повісті-казки лежить на фантастичних пригодах персонажах. 10) Леся Українка - це письменниця 3 величезної літери, яка сповнила українську літературу віршами для дітей. 11) Тарас Шевченко походив із родини кріпосників.

Завдання 11. Поданий науковий текст перекладіть українською.

Реформирование отечественного школьного образования будет эффективнее, если учитывать позитивный зарубежный опыт в этой сфере. Пример реформаторской деятельности британских правительств конца XX - начала XXI вв. свидетельствует о том, как последовательное структурное реформирование привело к существенному улучшению в системе общего среднего образования. Перспективными для украинского образования являются диверсификация среднего образования с соблюдением равных образовательных возможностей и социальной справедливости; практическое осуществление персонализации обучения; развитие инновационных школьных сетей; преобразование школы в центр общественной жизни путем предоставления обществу образовательных и социальных услуг (за К. В. Гаращуком).

Висновки та перспективи подальших наукових розвідок. Отже, систематична й послідовна робота 3 формування мовної культури студентів-нефілологів на заняттях з української мови (за професійним спрямуванням) може суттєво вплинути на рівень засвоєння ними норм сучасної української літературної мови. Перспективу для подальшого дослідження вбачаємо в розробці професійно орієнтованих завдань для удосконалення культури усного фахового мовлення.

\section{СПИСОК ВИКОРИСТАНИХ ДЖЕРЕЛ ТА ЛІТЕРАТУРИ}

1. Гриценко Т. Б. Українська мова та культура мовлення : [навч. посібник для студентів аграрних вищих навчальних закладів та коледжів] / Т. Б. Гриценко. - К. : Центр навчальної літератури, 2005. - 536 с.

2. Струганець Л. В. Культура мови : словник термінів / Л. В. Струганець. - Тернопіль : Навчальна книга Богдан, 2000. -88 с.

3. Культура української мови : довідник / С. Я. Срмоленко, Н. Я. Дзюбишина-Мельник, К. В. Ленець та ін. ; за ред. В. М. Русанівського. - К. : Либідь, 1990. - 304 с.

4. Підгурська В. Ю. Удосконалення культури мовлення майбутніх учителів початкових класів шляхом засвоєння норм літературної мови / В. Ю. Підгурська // Професійна освіта в умовах інтеграційних процесів : 
теорія і практика : [збірник наукових праць] / за заг. ред. проф. С. Вітвіцької. - Житомир : ФОП "Н. М. Левковець", 2017. - С. 167-170.

5. Івахненко Т. П. Місце і роль культури мови у фаховій підготовці студентів-нефілологів / Т. П. Івахненко // Наукові записки Національного університету "Острозька академія". Серія : Психологія і педагогіка. - 2014. Вип. 29. - С. 125-129.

6. Закон України. Про засади державної мовної політики [Електронний ресурс]. - Режим доступу : http://zakon3.rada.gov.ua/laws/show/5029-17.

7. Голубовська I. В. Використання міжпредметних зв'язків у процесі викладання курсу "Основи культури і техніки мовлення" / І.В. Голубовська // Вісник Житомирського державного університету імені Івана Франка. - 2005. - Вип. 21. - С. 32-34.

8. Про затвердження програм навчальної дисципліни "Українська мова (за професійним спрямуванням)" : наказ МОН № 1150 від 21.12.09 року [Електронний ресурс]. - Режим доступу : http: // osvita.ua /legislation/ Vishya osvita/6122/.

\section{REFERENCES (TRANSLATED \& TRANSLITERATED)}

1. Hrytsenko T. B. Ukrains'ka mova ta kul'tura movlennia : [navch. posibnyk dla studentiv ahrarnykh vyshchykh navchal'nykh zakladiv ta koledzhiv] [Ukrainian Language and Speech Culture] / T. B. Hrytsenko. - K. : Tsentr navchal'noi literatury, 2005. $-536 \mathrm{~s}$.

2. Struhanets L. V. Kul'tura movy : slovnyk terminiv [Language Culture : Terminology Dictionary] / L. V. Struhanets. - Ternopil : Navchalna knyha-Bohdan, 2000. - 88 s.

3. Kul'tura ukrainskoi movy : dovidnyk [Culture of the Ukrainian Language : reference book] / S. Ya. Yermolenko, N. Ya. Dziubyshina-Melnyk, K. V. Lenets ta in. ; za red. V. M. Rysanivskoho. - K. : Lybid, 1990. - 304 s.

4. Pidhurska V. Yu. Udoskonalennia kultury movlennia maibutnikh uchyteliv pochatkovykh klasiv shliahom zasvoiennia norm literaturnoi movy [Speech Culture Perfection of Future Elementary School Teachers by Mastering Literary Language Norm] / V. Yu. Pidhurska // Profesiina osvita v umovakh intehratsiinykh protsesiv : teoriia i praktyka [Professional Education in Conditions of Intergration Processes : Theory and Practice] : [zbirnyk naukovyh prats] / za zah. red. prof. S. Vitvitskoi. - Zhytomyr : FOP "N. M. Levkovets", 2017. - S. 167-170.

5. Ivakhnenko T. P. Mistse i rol' kultury movy u fakhovii pidhotovtsi studentiv-nefilolohiv [Place and Role of Language Culture in Professional Preparation of Students of Non-linguistic Specialties] / T. P. Ivakhnenko // Naukovi zapysku natsional'noho universytetu "Ostrozka akademiia". Seriia : Psyholohiia i pedahohika [Scientific Journal of National University "Ostroh Academy". Series: Psychology and Pedagogy]. - 2014. - Vyp. 29. - S. 125129.

6. Zakon Ukrainy. Pro zasady derzhavnoi movnoi polityky [Law of Ukraine. On Principles of the State Language Policy] [Elektronnyi resurs]. - Rezhym dostupu : http://zakon3.rada.gov.ua/laws/show/5029-17.

7. Holuboska I. V. Vykorystannia mizhpredmetnykh zviazkiv u protsesi vykladannia kursu "Osnovy kul'tury i tekhniky movlennia" [The Use of Intersubject Connections in the Process of Teaching Fundamentals of Culture and Speech Technique] / I. V. Holuboska // Visnyk Zhytomyrskoho derzhavnoho universitetu imeni I. Franka [Zhytomir Ivan Franko State University Journal]. - 2005. - Vyp. 21. - S. 32-34.

8. Pro zatverdzhennia program navchal'noi dystsypliny "Ukrains'ka mova (za profesiinym spriamuvanniam)" [On Adoption of Educational Programme of "Ukrainian Language (for Professional Purposes)" : Ministry of Education and Science of Ukraine Order No.1150 of 21 December 2009 [Elektronnyi resurs]. - Rezhym dostupu : http: // osvita.ua /legislation/Vishya_osvita/6122/.

\section{Голубовская И. В., Подурская В. Ю. Формирование языковой культуры будуцих специалистов на} занятиях по профессиональному украинскому языку.

В статье раскрыто суть понятий "культура языка" и "языковые нормы" в аспекте проблемы становления будущих специилистов. В частности рассмотрена проблема формирования языковой культуры студентов-нефилологов на занятиях по профессиональному украинскому языку; определено место учебного курса в системе подготовки бакалавров. Установлено иель и задания курса в контексте формирования творческой языковой коммуникативной личности будущзего специиалиста. Приведены

примеры практически ориентированных заданий по формированию умений и навыков правильного использования лексических, акцентуачионных, орфографических, стилистических, грамматических норм современного украинского литературного языка.

Ключевые слова: современный украинский литературный язык, языковая культура, профессиональный украинский язык, тренировочные упражнения.

\section{Holubovska I. V., Pidhurska V. Yu. Language Culture Formation of Future Specialists within the Framework of the Discipline Ukrainian Language (for Professional Purposes).}

The current state of Ukrainian higher education along with the general tendencies of its development poses new challenges to the professional preparation of modern graduates. The article focuses on the problem of language culture formation of students of non-linguistic specialties within the framework of the discipline "Ukrainian language (for professional purposes)". Being inseparable from culture and reflecting the intellectual level and 
creative potential of personality, language reveals his / her inner world. The article examines the notions "language culture" and "speech norms" with the reference to the problem of formation of future professionals. The course "Ukrainian language (for professional purposes)" is determined as the only linguistic discipline not only increasing general language training, language literacy, communicative competence of students of nonlinguistic specialties, practical mastering the basics of official-business, scientific, conversational styles of the Ukrainian language, but also expanding future specialists' outlook concerning language and speech culture. The place of the discipline as the component of the state standard of the Education Level of Bachelor Degree is specified. The authors define the main objective and tasks in the formation of creative future professionals as a clear definition and proper understanding of the role of the state language in professional activities; ensuring mastery of the rules of modern Ukrainian literary language and compliance culture of oral and written language; developing skills of self-control over compliance with the rules of language in communication. The article contains the examples of practically-oriented tasks for the formation of skills and habits of correct usage of lexical, accentual, orthographic and grammar norms of modern Ukrainian literary language. The article underlines the relevance of the following tasks in the process of teaching the course "Ukrainian language (for professional purposes)": reports on the problems of speech culture; training exercises for independent work; abstracting of suggested scientific works; compiling an accentual vocabulary; compiling a vocabulary of course terminology. Consecutive and consistent work during the classes of "Ukrainian language (for professional purposes)" directed at the formation of language culture of students of non-linguistic specialties has a potential of raising the level of students' mastering the norms of modern Ukrainian literary language. Further research of the issue can be focused on the development of professionally-oriented tasks aimed at professional speech culture improvement.

Key words: modern Ukrainian literary language, language culture, language norms, Ukrainian language (for professional purposes), training exercises. 